\title{
ALTERNATIVE METHODS FOR CONTROLLING COTTON ROOT ROT DISEASE
}

\author{
M.A. Awad ${ }^{(1)}$ ، Z.E. Khalifa(1) ${ }^{(1)}$ Fathia S. El-Shoraky ${ }^{(2)}$ and E.A. El-Waraky ${ }^{(3)}$ \\ (1) Agric. Botany Dept., Faculty of Agriculture, Menoufia University. \\ (2) Plant Pathology Research Institute, Agricultural Research Center, Giza, Egypt. \\ ${ }^{(3)}$ Cotton Research Institute, Agricultural Research Center, Giza, Egypt.
}

Received: Jul. 26, 2016

Accepted: Sep. 4, 2016

\begin{abstract}
Seventy one fungal isolates were isolated from cotton plants in Kafrelshiekh. These isolates were identified as Rhizoctonia solani, Fusarium sp., Macrophomina phaseolina and Scloratium rolfsii. Rhizoctonia solani was the most frequent fungus among the isolated fungi where it recorded 39.43\% followed by Fusarium sp. 29.57\%, Macrophomina phaseolina (23.49\%) while Sclerotium rolfsii was the least frequent fungus (7.04\%). Under artificial inoculation, cv. Giza 86 was the most highest infective one among the other tested cotton Cvs where was recorded with it. Percent of pre- and post- emergence. As for controlling cotton root rot disease. Some bioagent like (Bacillus Subtilis) and (Trichoderma harzianum), Bio- Zeid, Bioarc and Plant guard as commercial formula, in addition to antioxidants like salicylic acid, acetic acid and citric acid and microelements like iron chelate, zinc chelate and manganese chelate were tested. Against the causal pathogen of cotton root rot under greenhouse conditions. Under field, all treatments except citric acid and plant distance at $40 \mathrm{~cm}$ led to significant increase in percentage of survived plants. In this respect, B. subtilis, T. harzianum, Plant guard, Bio- arc, Salsylic acid, Rizolex-T and Moncut recorded efficiency more than $71.24 \%$ compared to check treatment. Most of the treatments did not show a significant increase in the disease severity except B. subtilis, T. harzianum, Plant guard, Bio- arc and Salsylic acid, which led to reduction significant in disease severity comparing to the control treatment. On the other hand, nonsignificant differences in boll weight as a result of using the various treatments, meanwhile there were significant different in the number of fruiting branches/plant. The highest number of fruiting branches were recorded with Bio-zeid and plant distance at $45 \mathrm{~cm}$, respectively during season 2014 and 2015. Also, there were clear significant differences between treatments for earliness index during two seasons. Whereas non-significant differences were recorded with seed index or lint\% among the different tested treatments.
\end{abstract}

Key words: Cotton, root rot disease. Control methods, plant distance, bioagents, fungicides, microelements

\section{INTRODUCTION}

Cotton Gossypium barbadense L. is one of the most important fiber crops in Egypt. Several fungal diseases attack cotton plants during different growth stages causing considerable losses in yield. Soil borne diseases are economically very important where they are responsible for over than two/third of the losses due to diseases infection. Cotton root rot comprises a group of that have almost similar symptoms.

Fusarium spp., Rhizoctonia solani, Macrophomina spp., Pythium spp. and
Sclerotium spp. are the most common pathogens causing damping-off and root rot of cotton. They may reduce the plant yield (Eid et al 1986 and Hashim and Ali, 2004).

These pathogens affect the plant population from emergence (pre- or post) to the end of plant age and decreased the potential productivity of the remaining plants. Rush and Kraft (1986).

Distribution of the soil borne pathogens is not homogenous in the soil. Some pathogens are present in some areas, but not in the others, as well as these 
pathogens affected by the growing seasons and previous crops grown in the same area (Kunichenko and Leontyan, 1990; Oyarzum et al., 1993; Demirci et al., 1999 and others).

Rhizoctonia solani was also reported as a causal organism of cotton damping off by many scientists. Ranney and Bird (1958), Lumsden et al. (1983) and Wang et al. (1992) demonstrated that Fusarium spp. are the causal organisms of cotton seedling root rot and damping-off.

To avoid fungicide hazards, considerable interest in the recent years has been given to the application of untraditional resistance methods by using of natural, biological and agricultural control methods.

On the other hand, Trichoderma harzianum and Bacillus subtilis showed antagonistic effects to the pathogen under study. Cook and Baker (1983) mentioned that about 35 genera of fungal and bacterial species have been used as biocontrol agents against various plant pathogens. They also indicated that Trichoderma spp., Bacillus spp., Pseudomonas spp. and actinomycetes represent the most antagonistic microorganisms.

Three antioxidants i.e., salicylic acid, acetic acid and citric acid were tested for controlling root rot diseases of cotton cv. Giza 86. Antioxidants were applied in these trails as seed soaking.

This study aimed to throw the light on possibility of using some bioagents, antioxidants, microelemints and plant distance as alternative methods of fungicides in controlling cotton root rot disease.

\section{MATERIALS AND METHODS Isolation of the causal organism:}

Isolation of the causal organisms was done diseased cotton plants showing root rot symptoms collected from five locations, i.e. Kafrelsheikh, Sede Salem, Desouk, Fowa and Qellien in Kafrelsheikh governorate. These infected cotton samples were mainly collected from open fields. The infected roots were cut into small pieces, washed thoroughly with running tap water to remove any adhering soil particles. Isolation was made form the cortex and vascular of the tap-root and secondary root where samples were surface sertilized by immersing then in $0.25 \%$ sodium hypochlorite solution for 2 minutes then rinsed in sterilized distilled water, dried between sterilized filter papers, and then transferred to Petri dishes containing Potato Dextrose Agar (PDA) medium supplemented with $(50 \mathrm{ppm})$ streptomycin sulfate $+(50$ units $/ \mathrm{ml}$ ) penicillin $+20 \mathrm{ppm}$ tetramycin to avoid any bacterial contamination. Plates were incubated at $28^{\circ} \mathrm{C}$ in the dark for 3 days and examined daily for the occurrence of mycelial growth (Mertely et al., 1991 and Awad, 2004).

The growing fungi were transferred to other plates containing the same medium. The isolated fungi were then purified using hyphal-tip or single spore technique to slants of PDA and incubated at $28^{\circ} \mathrm{C}$ for 5 days.

\section{Purification and identification of the isolated fungi:}

Pure cultures were obtained by selecting tips of the fungal isolates, which were marked and cut-off using a flamed flatted and sharp needle. Hyphal tip were transferred to PDA medium and incubated at $28^{\circ} \mathrm{C}$. Pure cultures of the growing fungi were examined morphologically and microscopically characteristics of mycelia and spores as described by Nelson et al. (1982), Barnett\& Hunter (1972), Pollack and Uecker (1974) in order to identify them at Agricultural Botany Department, Faculty of Agriculture, Menoufia University.

Frequency $\%$ of the isolated fungi from diseased plants, collected from the different cotton growing areas in Kafrelsheikh governorate, Egypt were calculated and tabulated.

Sources of Rhizoctonia solani, Fusarium sp., Macrophomina phaseolina and other isolates. 
Twenty eight isolate of $R$. solani, twenty one isolate of Fusarium spp. and seventeen isolate of $M$. phaseolina and five isolates of Sclerotium rolfsii originated from cotton seedlings were obtained by isolation from Kafrelsheikh governorate. (Table1).

\section{Isolation of antagonistic microorganisms:}

Roots of healthy cotton plants collected from heavily infested field soil were used to isolate different antagonistic microorganisms using the method described by Ahmed (2005). One gram of the soil around the root of cotton plants, on dry basis, was added aseptically to $99 \mathrm{ml}$ sterile water (to make stock dilution of 1/100) and shake periodically for approximately 15 minutes. In similar way, the stock soil suspension was used to make serial dilutions of $10^{2}$ to $10^{6}$. Autoclaved peptone dextrose agar + rose Bengal + streptomycin medium (Johnson, et al., 1960) and potato dextrose agar (PDA) and Nutrient agar medium (NA) were used for isolating the antagonistic fungi and bacteria.

Soil suspension of dilutions $10^{-4}$ (Johnson, et. al., 1960) and $10^{-6}$ (Lochhead, 1940) were used for isolating antagonistic fungi and bacteria, respectively. One $\mathrm{ml}$ of a known dilution was aseptically transferred to sterilized Petri-dishes each containing about $10 \mathrm{ml}$ of PDA or NA agar medium. Three plates were used for each dilution. All plates were incubated at $25 \pm 1^{\circ} \mathrm{C}$ for $2-4$ days. The isolated microorganisms, which grew in separate colonies on the dilution plates, were selected, sub-cultured and identified according to their morphological cultural and physiological characters (Comm, 1955 and Rifai, 1969).

\section{Pathogenicity tests and varietal resistance of cotton cultivars under greenhouse condations:}

This experiment was conducted to assess the pathogenic effect of isolated fungi (Fusarium. sp., Rhizoctonia solani and
Macrophomina phaseolina) against some commercial cotton cultivars, (Giza 70, Giza 86, Giza 87, Giza 88 and Giza 92), under greenhouse conditions. Plastic pots $(30 \mathrm{~cm}$ in diameter) containing $5 \mathrm{~kg}$ of sterilized sandy clay soil (1:3) were arranged as a completely randomized design on a bench of the glasshouse in Sakha Agricultural Research Station. Six pots were used as replicates for five cultivars as well as the untreated control. Each fungal isolate was singly grown on sterilized cornmeal-Sand medium in conical flasks $(500 \mathrm{ml})$ for two weeks at $28 \pm 2{ }^{\circ} \mathrm{C}$. The soil was infested with mix at a rate of $3 \%$ of each fungus culture, separately, by soil weight. The infested soil was watered daily for 7 days to obtain the optimum fungal growth and distributing of the pathogenic fungal growth before planting. Cotton seeds were surface sterilized by dipping in sodium hypochlorite solution $(0.1 \%)$ for $2 \mathrm{~min}$, and then the seeds were washed through serial sterilized distilled water before the planting. Ten seeds from each cotton cultivar, separately, were sown in each pot. The control pots were inoculated with the equal amount of uninoculated cornmeal -Sand medium. All pots were kept under greenhouse conditions and the disease assessments were recorded as the percentages of Preemergence damping-off at 15 days post sowing, while post-emergence damping-off, survivals, plant height $(\mathrm{cm} /$ plant) and dry weight (mg/plant) were recorded 45 days post sowing.

\section{Seed Treatment}

All experiments were conducted using the cotton cv. Giza 86, which are widely grown in Kafrelshiekh region.Before planting, cotton seeds were surfacedisinfested in $70 \%$ ethanol for 2 min, followed by $2 \mathrm{~min}$ in $0.3 \% \mathrm{NaOCl}$, then rinsed three times in sterile distilled water and placed to dry for 45 minutes in an antiseptic chamber.Seeds of cotton cultivar Giza 86 were treated with different treatments as maintained in Table (1). Untreated seed were used as a control. 
Awad et al.,

Table (1): Different treatments of cotton seeds cv. Giza 86 as seed dressing before planting.

\begin{tabular}{|c|c|c|}
\hline Treatment & composition & Application rate \\
\hline \multicolumn{3}{|c|}{ Bioagents } \\
\hline Bacillus subtilis & Bacillus subtilis & $2 \times 10^{7}$ \\
\hline Trichoderma harzianum & Trichoderma harzianum & $2 \times 10^{5}$ \\
\hline Bio zeid & Trichoderma album & $2 \mathrm{~g} / \mathrm{kg}$ seeds \\
\hline Plant-guard & Bacillus subtilis & $2 \mathrm{~g} / \mathrm{kg}$ seeds \\
\hline Bio-arc & Bacillus megaterium & $2 \mathrm{~g} / \mathrm{kg}$ seeds \\
\hline \multicolumn{3}{|c|}{ Antioxidants } \\
\hline Salicylic acid & salicylic acid & $0.125 \mathrm{~g} / \mathrm{kg}$ seeds \\
\hline Acetic acid & Acetic acid & $0.125 \mathrm{~g} / \mathrm{kg}$ seeds \\
\hline Citric acid & Citric acid & $0.125 \mathrm{~g} / \mathrm{kg}$ seeds \\
\hline \multicolumn{3}{|c|}{ Fungicide } \\
\hline Rizolex T 50 WP & $\begin{array}{l}\text { a) O-2,6-dichloro-p-tolyl o,o } \\
\text { dimethyl phosphorothioate } \\
\text { b) Tetra methylthiuram } \\
\text { disulfiode;bis(dimethylthiocar } \\
\text { bamoyt)disulfide }\end{array}$ & $2 \mathrm{~g} / \mathrm{kg}$ seeds \\
\hline Moncut. 25\% WP & $\begin{array}{l}\text { A,a,a-trifluoro-3-isopropoxy-0- } \\
\text { toluanilide }\end{array}$ & $2 \mathrm{~g} / \mathrm{kg}$ seeds \\
\hline \multicolumn{3}{|c|}{ Microelements } \\
\hline Iron chelate & Iron chelate $13 \%$ & $1 \mathrm{~g} / \mathrm{L}$ water \\
\hline Zinc chelate & Zinc chelate $13 \%$ & $1 \mathrm{~g} / \mathrm{L}$ water \\
\hline Manganese chelate & Manganese chelate $13 \%$ & $1 \mathrm{~g} / \mathrm{L}$ water \\
\hline
\end{tabular}

\section{The diseases assessments:}

The diseases assessments as the percentages of pre, post-damping off and root- rot were recorded at 15 and 30 days of the planting respectively.

Percentages of pre and post-emergence damping-off as well as survival plants and disease severity (DS) were estimated up to 45 days from planting as described by Arafa (1985) as follow:

- Percentage of pre-emergence dampingoff was determined after 15 days as:

Pre-emergence damping-off $(\%)=$

No. of un-germinated seeds / pot

No. of sown seeds / pot

- Percentage of post-emergence damping off was determined after 30 days as:
Post-emergence damping-off $(\%)=$ No. of died seedlings /pot

Total No. of emerged seedlings / pot

- Percentage of survived plants was determined after 45 days at the end of experiment as:

Survival plants $(\%)=$

No. of healthy un-infected plants with root-rot $/$ pot $^{\star}$

Total No. of plants / pot

Survival or healthy plants ${ }^{*}=($ No. of sowing seeds - pre and post emerging damping off).

Rhizoctonia canker severity in the cotton plants was assessed 30 days after sowing, using a score scale ranging from 0 to 4 (Noronha et al., 1995), where:

$0=$ no symptoms,

$1=$ hypocotyl with small lesions, 
$2=$ hypocotyl with big lesions, without constriction,

$3=$ completely constricted hypocotyl, showing damping-off

$4=$ non-germinated seeds and/or nonemerged seedlings.

The percent stand counts and plant dry weights per pot were recorded. Roots of 10 plants from each plot were sampled and rated for root rot. Root rot severity was assessed on a scale of 0 to 4 , (Howard \& Thomas 2000) where:

0 = healthy

$1=$ small brown lesions on $<25 \%$ of exterior ircumference of the tap root

2 = lesions on $25-49 \%$ of tap root

$3=$ lesions on $50-74 \%$ and tap root constricted

4 = tap root girdled (75-100\%) and plant wilted or dead.

\section{Field Experiments for disease control:}

Field trials were conducted in two seasons 2012/2013 at Sakhaa Agricultural Research Station. The trials were planted in 25, 30 March 2012 and 2013, respectively. Plots were 4 rows wide (60 cm row spacing), $5 \mathrm{~m}$ long, and planted at a population of 200 seeds per row. Each row included 20 hills, each containing 10 seeds of cotton cv. Giza 86. Seeding depth was $5 \mathrm{~cm}$. The previous crops were flax then by cotton. The treatments were arranged in a complete randomize design with three replications.

\section{Effect of bioagents and commercial Bio-formulations:}

Commercial bio-formulations of, plantguard, Bio-zeid and Bio-arc in addition to $T$. harzianum and $B$. subtilis were evaluated under field conditions. Cotton seeds cv. Giza 86 were treated with biological treatments at the recommended dose of all commercially bio- formulations by Ministry of Agricultural. Biological treatments were added to slightly moist seeds and allowed before being planted.

\section{Antioxidant treatments:}

Salicylic acid, acetic acid and citric acid were used as seed treatment against cotton root rot diseases under field condition:
Seeds of cotton were soaked in salicylic, acetic, citric acid solution individually for $2 \mathrm{~h}$, before planting in soil. Non-treated seeds served as control

\section{Effect of microelements:}

The present study concerned with the effect of micro-elements on root rot diseases on cotton plants under field conditions of the following chelated chemicals manganese, zinc and iron at $1 \mathrm{~g} /$ liter. Seeds were soaked by each micro-element for 2 hours before planting.

\section{Fungicide treatments:}

To study the effect of Rizolex T. and Moncut on the root rot diseases. Cotton seeds cv Giza 86 were treated with each fungicide at the recommended dose for 2 hours before planting. Arabic gum was used as a sticker with seed dressing. Untreated seeds assembled control treatments for each treatment.

\section{Studied characters:}

\section{Yield and its components} characters:

- Boll weight (BW. g): The average weight of five sound open bolls in gram.

- Seed Cotton yield/plant (SCY. g): Weight of seed cotton yield per plant in gram.

- Lint percentage (LP. \%): It was estimated as the ratio lint yield to seed cotton yield.

- Seed index (SI, g): Weight of 100 seeds in gram.

- Earliness index (El. \%): It was calculated as follows:

Earliness index $(\%)=$ First picking

First picking + second picking $\times 100$

- Lint index (LI. g): Weight of lint produced by 100 seeds. It was estimated using the formula as follows:

Lint index $(g)=\frac{\text { Seed index } x \text { Lint percentage }}{100-\text { Lint percentage }}$ 


\section{Statistical of plant Analysis}

The randomized complete block design was used. The data were subjected to analysis of variance (ANOVA) using XLSTAT PRO statistical analysis software (Addinsoft). The experiments were repeated at least three times, and treatment means were separated using a Fisher's least significant difference (LSD) test. All analyses were conducted at a significance value of $P$ $\leq 0.05$.

\section{RESULTS Isolation and identificationof cotton soil borne pathogens:}

Isolation trails were carried out from diseased samples collected from different locations i.e., Kafrelsheikh, Sede-Salem, Desouk, Fowa and Qallein in Kafrelsheikh Governorate.. Seventy one fungal were isolated from cotton plants. These isolates were identified as Rhizoctonia solani,
Fusarium sp., Macrophomina phaseolina and Scloratium rolfsii.

Rhizoctonia solani recorded the highest frequency\% among the other isolsted fungi from infected cotton plants where it recorded $39.43 \%$ followed by Fusarium spp. $29.57 \%$, and Macrophomina phaseolina (23.49\%) while Sclerotium rolfsii recorded the least percent of isolated fungi $7.04 \%$, as shown in Table (2).

\section{Pathogenicity test and varietal resistance of cotton cultivars under greenhouse condition.}

Data in Table (3) exhibit varietal reaction of some cotton cvs under the artificial inoculation. In this respect cv. Giza 86 had the highest percent of pre-emergence (54.64) while cv Giza 87 was the lowest one (19.5\%).

Table (2). Frequency number of soil borne isolated fungi from soil borne of cotton plants grown inKafrelsheikh Governorate.

\begin{tabular}{|c|c|c|c|c|c|c|}
\hline Governorate & Locations & $\begin{array}{c}R . \\
\text { solani }\end{array}$ & $\begin{array}{c}\text { Fusarium } \\
\text { spp. }\end{array}$ & $\begin{array}{c}\text { M. } \\
\text { phseolina }\end{array}$ & S. rolfsii & $\begin{array}{l}\text { n. of } \\
\text { isolates }\end{array}$ \\
\hline \multirow{5}{*}{ 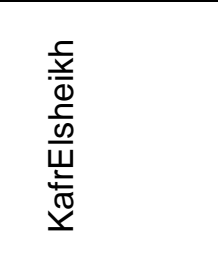 } & Kafrelsheikh & 3 & 4 & 3 & 1 & 11 \\
\hline & Sede-Salem & 7 & 4 & 5 & 1 & 17 \\
\hline & Desouk & 12 & 7 & 6 & 2 & 27 \\
\hline & Fowa & 2 & 3 & 2 & 1 & 8 \\
\hline & Qallien & 4 & 3 & 1 & 0 & 8 \\
\hline $\begin{array}{l}\text { Number of } \\
\text { isolated }\end{array}$ & & 28 & 21 & 17 & 5 & 71 \\
\hline Frequency \% & & 39.43 & 29.57 & 23.94 & 7.04 & \\
\hline
\end{tabular}

Table (3). Reaction of some commercial cotton cultivars to Rhizoctonia solani infection under greenhouse conditions.

\begin{tabular}{|c|c|c|c|c|}
\hline \multirow[b]{2}{*}{ Cotton commercial cvs } & \multicolumn{2}{|c|}{ Damping-off \% } & \multirow{2}{*}{$\begin{array}{c}\text { Survivals } \\
\%\end{array}$} & \multirow{2}{*}{$\begin{array}{c}\text { \%infection } \\
\text { R. solani }\end{array}$} \\
\hline & $\begin{array}{c}\text { Pre- } \\
\text { Emergence }\end{array}$ & $\begin{array}{c}\text { Post- } \\
\text { Emergence }\end{array}$ & & \\
\hline Giza 70 & 38.4 & 10.0 & 51.6 & 34.5 \\
\hline Giza 86 & 54.6 & 14.9 & 30.5 & 45.6 \\
\hline Giza 87 & 19.5 & 7.1 & 73.4 & 44.4 \\
\hline Giza 88 & 31.4 & 11.3 & 57.3 & 40.0 \\
\hline Giza 92 & 53.7 & 9.3 & 37.0 & 37.25 \\
\hline LSD at 0.05 & 1.459 & 1.635 & 1.219 & 1.339 \\
\hline
\end{tabular}


All cultivars produced post-emergence percent ranged from 7.1 to $14.9 \%$. Giza 87 was the most resistant, where, it had the highest survival percent of plant (73.4\%) while cv Giza 86 was the lowest one $(30.5 \%)$ and the most infective fungus was R. solani.

\section{Evaluation of different treatments on pre-, post- emergence and survival percentage, root rot, dry weight under greenhouse conditions:}

Data in Table (4) reveal that there were significant differences as between treatments in the determined disease assessments. In the respect $(P \leq 0.05)$ increased occurred for seedling emergence. Pre- emergence decrease was high with $B$. subtilis, salsylic acid and citric acid seeds treatments $(0.00 \%)$ compared with nontreated seeds $(30.0 \%)$, with significant differences between treatments the differences were not significant in postemergence percent compared with control treatment. The most of treatments recorded $80-100 \%$ of survived compared with nontreated seeds. The canker severity of most treatments was not significant except Bioarc, Rizolex-T, Moncut and iron chelate which had the less significant reaction. Root rot severity was decreased significantly by treating seeds except some treatments which were not significant effective in decreasing cotton root rot disease comparing to control (Bio-zeid, Salsylic acid, Acitic acid, Citric acid, zinc chelate and manganese chelate). T. harzianum, Rizolex $50 \%$, B. subtilis, Acetic acid and zinc chelate treatments increased the seedling dry weight significantly comparing to control.

\section{Field Experiment:}

Data in Table (5) show that results of treated cotton seeds with different treatments led to increasing the percentage of the survival plants, in this respect ( $B$. subtilis) recorded a significant increase comparing to plant distance at $25 \mathrm{~cm}$ as the check treatment, it observe that all treatments except citric acid and plant density $40 \mathrm{~cm}$ led to significant increase in survived plants percent. It can be expressed through the measurement of the efficiency of treatments for the check treatment, where B. subtilis, T. harzianum, Plant guard, Bio- arc, Salsylic acid, Rizolex$\mathrm{T}$ and Moncut recorded efficiency more than $71.24 \%$ compared to check treatment. Most of treatments did not show a significant increase in the disease severity except $B$. subtilis, T. harzianum, Plant guard, Bio- arc and Salsylic acid, which reduced disease severity significantly comparing to the control treatment.

\section{Yield and its components characters:}

Cotton yield is very important character due to cotton yield affected by more factor i.e. Genetic, fertilizers, sowing date, diseases, insects and climate changes and other factors.

All of the above factors affect growth of cotton crop and production components and quality.

Therefore, it was necessary to use different means to avoid the pressure caused by previous exposure factors.

Among the most serious factors affecting production and quality are diseases especially root rot disease on cotton crop.

Many methods could be used for controlling root rot disease like ( $T$. harzianum and $B$. Subtilis), bio-formulations (Bio-zeid, Bio-arc and plant guord), antioxidants as Salsylic, citric, acetic acids, chemical fungicides (Rhizolex-T, Moncut), plant density $(25 \mathrm{~cm}, 40 \mathrm{~cm}, 45 \mathrm{~cm}$ and 50 $\mathrm{cm}$ ) and microelements (iron, zinc and manganese chelate.

\section{Boll weight:}

Data in Table (6) and (7) show that there are non-significant differences in boll weight 
Awad et al.,

as a result of using various treatment, where, all treatments increased the boll weight comparing to control plants (plant density $25 \mathrm{~cm}$ ) during seasons 2014 and 2015 , respectively. On the other hand, nonsignificant increases have been achieved in boll weight of treatment with T.harzinum during seasons 2014 and 2015, respectively.

\section{The number of fruiting branches/} plant:

The results in Table (6) and (7) indicated to clear significant differences in the number of fruiting branches per plant in treated cotton plants. The highest number of fruiting branches were achieved with Bio-zeid and plant distance at $45 \mathrm{~cm}$ respectively during seasons 2014 and 2015.

Table (4). Effect of different treatments on pre- and post- emergence \%, survival \%, Canker severity, root rot severity and dry weight/g in cotton seeds (cv. Giza 86) infected by $R$. solani under greenhouse conditions.

\begin{tabular}{|c|c|c|c|c|c|c|}
\hline Treatment & $\begin{array}{c}\text { Pre- } \\
\text { emergence } \\
\%\end{array}$ & $\begin{array}{c}\text { Post- } \\
\text { emergence } \\
\%\end{array}$ & survival \% & $\begin{array}{c}\text { Canker } \\
\text { severity \% }\end{array}$ & $\begin{array}{l}\text { Root rot } \\
\text { severity\% }\end{array}$ & $\begin{array}{c}\text { Seedling } \\
\text { dry weight } \\
/ g\end{array}$ \\
\hline \multicolumn{7}{|c|}{ Bioagent } \\
\hline B. subtilis & 0.0 & 0.0 & 100.0 & 2.3 & 0.67 & 0.099 \\
\hline T. harzianum & 20.0 & 25.0 & 70.0 & 2.17 & 0.67 & 0.167 \\
\hline Bio-zeid & 30.0 & 20.0 & 50.0 & 1.67 & 1.67 & 0.067 \\
\hline Plant-guard & 30.0 & 0.0 & 70.0 & 3.00 & 0.67 & 0.066 \\
\hline Bio-arc & 10.0 & 10.0 & 80.0 & 1.00 & 0.67 & 0.076 \\
\hline \multicolumn{7}{|c|}{ Antioxidant } \\
\hline Salsylic acid & 0.0 & 0.0 & 100.0 & 1.50 & 1.67 & 0.066 \\
\hline Acetic acid & 10.0 & 0.0 & 90.0 & 2.50 & 1.67 & 0.091 \\
\hline Citric acid & 0.0 & 20.0 & 80.0 & 1.67 & 1.33 & 0.072 \\
\hline \multicolumn{7}{|c|}{ Fungicide } \\
\hline Rizolex-T 50\% & 10.0 & 30.0 & 60.0 & 0.33 & 0.67 & 0.114 \\
\hline Moncut 25\% & 10.0 & 20.0 & 70.0 & 0.67 & 0.67 & 0.073 \\
\hline \multicolumn{7}{|c|}{ Micro elements } \\
\hline Iron chelated & 20.0 & 10.0 & 70.0 & 0.03 & 0.67 & 0.067 \\
\hline Zinc chelated & 10.0 & 10.0 & 80.0 & 1.33 & 1.00 & 0.081 \\
\hline $\begin{array}{l}\text { Manganese } \\
\text { chelated }\end{array}$ & 30.0 & 10.0 & 60.0 & 1.67 & 1.67 & 0.075 \\
\hline Control & 30.0 & 20.0 & 50.0 & 2.83 & 2.33 & 0.074 \\
\hline LSD at 0.05 & 1.3 & 0.94 & 1.28 & 0.34 & 0.49 & 0.231 \\
\hline
\end{tabular}

Canker severity in the cotton plants as score scale ranging from 0 to 4 , where: $0=$ no symptoms, and $4=$ non-germinated seeds and/or non-emerged seedlings

Root rot severity as a scale of 0 to 4 , where: 0 = healthy; and $4=$ tap root girdled $(75-100 \%)$ and plant wilted or dead. 
Table (5). Effect of different treatments on survival\%, disease severity and the efficacy percentage of $\boldsymbol{R}$. solani infection in cotton (cv. Giza 86 ) under field conditions.

\begin{tabular}{|c|c|c|c|}
\hline Treatment & Survival \% & $\begin{array}{c}\text { Disease } \\
\text { Severity\% }\end{array}$ & Efficacy \% \\
\hline \multicolumn{4}{|c|}{ Bioagents } \\
\hline B. subtilis & 77.00 & 0.33 & 85.80 \\
\hline T. harzinum & 64.67 & 0.62 & 73.39 \\
\hline Bio-zeid & 57.33 & 1.33 & 42.91 \\
\hline Plant guard & 61.33 & 0.67 & 71.24 \\
\hline Bio-arc & 49.00 & 0.67 & 71.24 \\
\hline \multicolumn{4}{|c|}{ Antioxidants } \\
\hline Salsylic acid & 56.67 & 0.67 & 71.24 \\
\hline Acetic acid & 57.33 & 1.67 & 28.32 \\
\hline Citric acid & 42.00 & 1.00 & 57.08 \\
\hline \multicolumn{4}{|c|}{ Fungicides } \\
\hline Rizolex-T 50\% WP & 60.67 & 0.33 & 85.80 \\
\hline \multirow[t]{2}{*}{ Moncut 25\% WP } & 62.00 & 0.42 & 81.97 \\
\hline & Microelemer & & \\
\hline Iron Chelate & 48.67 & 1.33 & 42.91 \\
\hline Zinc Chelate & 54.00 & 1.00 & 57.08 \\
\hline Manganese Chelate & 57.33 & 1.00 & 57.08 \\
\hline \multicolumn{4}{|c|}{ Plant density } \\
\hline $25 \mathrm{~cm}$ (control) & 44.67 & 2.33 & - \\
\hline $40 \mathrm{~cm}$ & 46.00 & 1.67 & 28.32 \\
\hline $45 \mathrm{~cm}$ & 58.33 & 1.33 & 42.91 \\
\hline $50 \mathrm{~cm}$ & 50.00 & 1.33 & 42.91 \\
\hline LSD at 0.05 & 1.34 & n.s & - \\
\hline
\end{tabular}


Awad et al.,

Table (6): Effect of untraditional control methods on cotton yield and its components in 2012 cotton growing season.

\begin{tabular}{|c|c|c|c|c|c|c|c|}
\hline \multirow[t]{2}{*}{ Treatment } & \multicolumn{7}{|c|}{ Characters } \\
\hline & $\mathrm{Bw} / \mathrm{g}$ & $\mathrm{nfb} / \mathrm{p}$ & $\mathrm{El} \%$ & LI\% & $\mathrm{SI}$ & LP\% & $\begin{array}{l}\text { SCY } \\
\text { k/fed. }\end{array}$ \\
\hline \multicolumn{8}{|c|}{ Bioagents } \\
\hline B. subtilis & 2.440 & 19.80 & 60.91 & 6.19 & 12.70 & 36.84 & 10.83 \\
\hline T. harzianum & 2.920 & 21.07 & 62.62 & 7.27 & 13.38 & 34.37 & 15.91 \\
\hline Bio-zeid & 2.830 & 22.00 & 58.85 & 3.96 & 13.27 & 36.09 & 14.30 \\
\hline Plant guard & 2.540 & 16.00 & 49.97 & 6.04 & 13.08 & 36.50 & 11.02 \\
\hline Bio-arc & 2.430 & 15.13 & 60.12 & 6.97 & 13.06 & 36.66 & 17.15 \\
\hline \multicolumn{8}{|c|}{ Antioxidants } \\
\hline Salicylic acid & 1.760 & 16.40 & 46.60 & 6.25 & 12.45 & 35.92 & 13.67 \\
\hline Acetic acid & 2.350 & 15.40 & 52.41 & 5.84 & 12.81 & 36.14 & 10.20 \\
\hline Citric acid & 2.380 & 15.53 & 53.76 & 6.82 & 13.66 & 36.58 & 17.33 \\
\hline \multicolumn{8}{|c|}{ Fungicides } \\
\hline Rhizolex-T & 2.440 & 14.33 & 66.12 & 5.18 & 13.12 & 36.38 & 18.18 \\
\hline Moncut & 2.070 & 14.33 & 60.60 & 8.57 & 12.49 & 37.41 & 11.49 \\
\hline \multicolumn{8}{|c|}{ Plant density } \\
\hline $25 \mathrm{~cm}$ (control) & 1.850 & 14.07 & 51.31 & 7.45 & 11.44 & 37.86 & 8.95 \\
\hline $40 \mathrm{~cm}$ & 2.460 & 14.13 & 62.91 & 7.24 & 12.91 & 36.89 & 11.14 \\
\hline $45 \mathrm{~cm}$ & 2.360 & 20.53 & 57.70 & 5.54 & 13.00 & 35.42 & 17.47 \\
\hline $50 \mathrm{~cm}$ & 2.300 & 15.73 & 39.44 & 7.94 & 12.38 & 36.48 & 11.48 \\
\hline \multicolumn{8}{|c|}{ Microelements } \\
\hline Iron chelate & 2.520 & 13.20 & 55.03 & 8.48 & 13.03 & 38.79 & 13.85 \\
\hline Zinc chelate & 2.660 & 14.80 & 62.63 & 6.61 & 12.55 & 37.81 & 14.60 \\
\hline $\begin{array}{l}\text { Manganese } \\
\text { chelate }\end{array}$ & 2.520 & 14.87 & 57.44 & 7.19 & 12.74 & 37.90 & 16.51 \\
\hline LSD at 0.05 & Ns & 2.39 & 1.17 & 2.26 & Ns & Ns & 2.12 \\
\hline
\end{tabular}

$\mathrm{Bw} / \mathrm{g}=$ boll weight, $\mathrm{SCY} / \mathrm{g}=$ seed cotton yield $/$ plant, $\mathrm{LP}=$ lint percentage, $\mathrm{SI}=$ seed index, $\mathrm{El} \%=$ earlinesS index and $\mathrm{LI}=$ lint index 
Table (7): Effect of untraditional control methods on cotton yield and its components in 2013 cotton growing season.

\begin{tabular}{|c|c|c|c|c|c|c|c|}
\hline \multirow{2}{*}{ Treatment } & \multicolumn{7}{|c|}{ Characters } \\
\hline & $\mathrm{Bw} / \mathrm{g}$ & $\mathrm{nfb} / \mathrm{p}$ & $\mathrm{El} \%$ & LI\% & $\mathrm{SI} / \mathrm{g}$ & LP\% & SCY k/fed. \\
\hline \multicolumn{8}{|c|}{ Bioagnt } \\
\hline B. subtilis & 2.41 & 19.93 & 60.10 & 7.75 & 13.10 & 36.60 & 10.23 \\
\hline T. harzianum & 2.89 & 19.93 & 63.70 & 6.77 & 14.30 & 34.20 & 14.99 \\
\hline Bio-zeid & 2.59 & 21.80 & 61.90 & 7.46 & 13.30 & 35.90 & 14.52 \\
\hline Plant guard & 2.36 & 14.07 & 50.00 & 7.04 & 12.80 & 36.30 & 11.20 \\
\hline Bio-arc & 2.20 & 13.80 & 59.30 & 7.42 & 12.90 & 36.50 & 16.71 \\
\hline \multicolumn{8}{|c|}{ Antioxidants } \\
\hline Salicylic acid & 2.85 & 16.53 & 44.30 & 7.35 & 13.20 & 35.70 & 13.32 \\
\hline Acetic acid & 2.23 & 15.80 & 61.30 & 7.47 & 13.40 & 35.80 & 8.77 \\
\hline Citric acid & 2.29 & 15.00 & 56.00 & 7.47 & 13.10 & 36.30 & 19.00 \\
\hline \multicolumn{8}{|c|}{ Fungicides } \\
\hline Rhizolex-t & 2.35 & 14.73 & 56.10 & 7.49 & 13.30 & 36.10 & 13.54 \\
\hline Moncut & 2.10 & 16.27 & 55.60 & 7.61 & 12.90 & 37.10 & 12.51 \\
\hline \multicolumn{8}{|c|}{ Plant density } \\
\hline $25 \mathrm{~cm}$ (control) & 1.87 & 13.67 & 50.70 & 7.04 & 11.60 & 37.60 & 9.53 \\
\hline $40 \mathrm{~cm}$ & 2.45 & 14.60 & 71.20 & 7.62 & 13.20 & 36.60 & 10.48 \\
\hline $45 \mathrm{~cm}$ & 2.17 & 20.67 & 59.60 & 7.10 & 13.10 & 35.10 & 10.40 \\
\hline $50 \mathrm{~cm}$ & 2.25 & 14.60 & 41.60 & 7.33 & 12.90 & 36.20 & 11.25 \\
\hline \multicolumn{8}{|c|}{ Microelements } \\
\hline Iron chelate & 2.47 & 13.27 & 57.50 & 8.27 & 13.00 & 38.50 & 14.20 \\
\hline Zinc chelate & 2.45 & 14.27 & 65.60 & 7.76 & 12.90 & 37.50 & 13.85 \\
\hline Manganese chelate & 2.40 & 14.33 & 61.30 & 7.71 & 13.20 & 36.80 & 17.06 \\
\hline LSD at 0.05 & Ns & 2.62 & 1.11 & Ns & Ns & ns & 1.97 \\
\hline
\end{tabular}

$\mathrm{Bw} / \mathrm{g}=$ boll weight, SCY $/ \mathrm{g}=$ seed cotton yield/plant, $\mathrm{LP}=$ lint percentage, $\mathrm{SI}=$ seed index, $\mathrm{El} \%=$ earliness index and $\mathrm{LI}=$ lint index. 


\section{Earliness index:}

The results clear that there are significant differences between treatments for earliness index in the two seasons. Also, the results exhibited that control treatment and plant distance at $50 \mathrm{~cm}$ gave low value of earliness index (51.3 and 39.44\%). On the other hand, some treatments like (Bacillus, Trichoderma, Bio-zeid, Rhizolex-T, plant distance $40 \mathrm{~cm}$ and zinc chelate were effective positively more than other treatments on earliness comparing control, while in the second season, the superior treatment were Bacillus, Trichoderma, Bioarc, acetic acid, plant distance $40 \mathrm{~cm}$, zinc chelate and manganese chelate.

\section{Lint index:}

Data in Table (6) indicated to significant differences in lint index under all different treatments. The highest increasing in lint index were recorded with iron chelate, plant distance $50 \mathrm{~cm}$, plant density $45 \mathrm{~cm}$ and $T$. harzianum respectively, in season 2014, while, non-significant differences in lint index under all different treatments during season 2015, were recorded.

\section{Seed index:}

Data in Table (6) and (7) show that there are non-significant differences between treatments in seed index.

\section{Lint percentage:}

Data in Table (6) and (7) show that there are non-significant differences between treatments in lint index.

\section{Seed cotton yield:}

The results clear that most treatments increased productively of seed cotton yield compared with control (Plant distance 25 $\mathrm{cm}$ ) during season 2014, where the highest productivily of cotton seeds were recordedwith Rhizolex-T, plant distance at $45 \mathrm{~cm}$ and citric acid respectively, during season 2014. Followed by Bio-arc and manganese chelate. Similar trend was noticed in the second season.
The previous results showed that using some treatments (citric acid, manganese chelate and Bio-arc on Giza 86 cultivar help the farmer to produce high yield comparing with control.

\section{Discussion}

Treating of cotton seeds by soaking in antioxidants in applied greatly affected positively cotton root rot disease comparing to control treatment. The least root rot was recorded by soaking cv Giza 86 seeds in salsylic acid. Also, antioxidants promoted plant growth and yield components.

Many investigators obtained similar results on many soil pathogens and plants like Mansour (2005), Aleandri et al. (2007) and Aaleandri et al., (2010).

Fe can control or reduce the disease severity of several diseases such as rust in wheat leaves, smut wheat and Colletotrichum musae in banana (Graham and Webb, 1991). Foliar application of Fe can increase resistance of apple and pear to Sphaeropsis malorumand cabbage to Olpidium brassicae Also, in cabbage the addition of Fe overcame the fungus-induced Fe deficiency in the host but it did not affect the extent of infection (Graham and Webb, 1991).

Manganese is probable the most studied micronutrient about its effects on disease and is important in the development of resistance in plants to both root and foliar diseases. Mn availability in the soil varies and depends on many environmental and soil biotic factors. $\mathrm{Mn}$ is required in much higher concentration by higher plants than by fungi and bacteria and there is opportunity for the pathogen to exploit this difference in requirement (Marschner, 1995).

Zinc was found to have a number of different effects as in some cases it decreased, in others increased, and in others had no effect on plant susceptibility to disease In most cases, the application of $\mathrm{Zn}$ reduced disease severity, which could be 
because of the toxic effect of $\mathrm{Zn}$ on the pathogen directly and not through the plant's metabolism (Graham and Webb, 1991).

Microelements affect on percent disease severity $\%$ and efficacy\% and play role on plant growth parameters, anatomical features and yield components. The results mean that these microelement treatments enhance and stimulate the biosynthesis of leaf pigments Wassel et al., (2000).

Yield and its components characters For the impact of untraditional control methods to root rot diseases on cotton yield components in 2012, 2013 cotton growing seasons were showed that the significant increasing in cotton yield components (boll weight, number of fruit branch/plant, earliness index, lint index, seed index, lint percentage and seed cotton yield) by rates comparison with untreated plants. These results were mostly agreeable with results reported by (Shehat et al., 2000; Nichols et al., 2009 and Jahedi et al., 2013).

Also, appeared that seed index, lint percentage, lint index, number of branch/plant, bool weight, earliness index and seed cotton yield significantly increased over the control through two seasons. The results were in general agreement with those obtained by Wassel et al., (2000) and El-Sabbagh et al., (2002).

\section{REFERENCES}

Awad, H. M. (2004). Studies on root-rot disease of pea. M. Sc. Thesis in Agric. Sciences (plant pathology), Fac. Of Agriculture, Menoufia Univ., pp.172.

Ahmed, M. F. A. (2005). Effect of adding some biocontrol agents on non-target microorganisms in root diseases infecting soybean and broad bean plants. M.Sc. Thesis. Faculty of Agriculture Moshtohor, Benha Univ., 137 pp.

Arafa, M.K.M. (1985). Studies on Fusarium wilt of cumin. M.Sc. Thesis, Assiut University, Egypt.
Aleandri, M.P., Reda, Buzi, A., P. Magro and G. Chilosi (2007). Induction of resistance in melon against soil-borne fungal pathogens by treatments with chmical resistance inducees. Joint International Workshop on: Pr-Proteins and induced resistance against pathogens and insects. Doorn. Netherlands.

Aleandri, M.P., R. Reda, V. Tagliavento, P. Magro and G. Chilosi (2010). Effect of chemical resistance inducers on the control of Monosporascus root and vie decline of melon. PhytopathologiaMediterranea, 49:512515.

Barnett, H.L. and B.B. Hunter (1972). Illustrated genera of imperfect fungi. Minnesota Burges Publ. Co, p. 241.

Cook, R.J. and K.F. Baker (1983). The nature and practice of biological control of plant pathogens. St. Paul., Minn. Am. Phytopathol. Soc., 539 pp.

Comm, O. A. J. (1955). Endospore-forming rods and cocci, Genus Bacillus. Borges's Manual of Determinative Bacteriology, pp. 201-217.

Demirci, E., C. Eken and F. Kanter (1999). Wilt and root rot pathogens of chicken cv. "Aziziye-94". Journal of Plant Pathology, 80(2): 175.

Eid, E.T., M.H. Abdel $-\mathrm{Al}$ and M.S. Ismail (1986). Comparative study on some Egyptian and Amrican cotton varieties under certain chemical treatments of growth regulators. Annals of Agric., Moshtohor, Vol. 24(3).

El-Sabbagh, A.A., S.A. Abd El-Hafez, A.Z. El-Bably and E.I. Abou- Ahmed (2002). Cotton response to frequent irrigation and foliar application of som micronutrients $\mathrm{J}$. Agric. Res., Tanta Univ., 28(1):193-205.

Graham, RD, M.J. Webb (1991). Micronutrients and disease resistance and tolerance in plants. In: Mortvedt JJ, Cox FR, Schuman LM, Welch RM (eds) Micronutrients in agriculture. Madison Wis : Soil SciSoc America, pp 329-370

Hashem, M. and E. Ali (2004). Epicoccumnigrum as biocontrol agent of 
Pythium damping off and root-rot of cotton seedlings. Arch. Phytopathol. Plant. Prot. 37: 283-297.

Howard, R. J. and A. G. Thomas (2000). Effect of temperature, seeding date, fungicide seed treatment and inoculation with Fusarium avenaceum on seedling survival, root rot severity and yield of lentil. Can. J. Plant Sci. 80: 899_907.

Johnson, L. F., E. A. Curl, J. H. Bond and H. A. Fribourg (1960). Methods for studying soil microfora-plant disease relationship. Burgess, Minneapolis. $178 \mathrm{pp}$.

Kunichenko, N.A. and N.I. Leontyan (1990). Seed treatment for vegetable peas. ZashchitaResteniiMoskova 2: 16-17.

Lochhead, A. G. (1940). Qualitative studies of soil microorganisms. III. Influence of plant growth on the characters of the bacterial flora. Cand. J. Research, 18: 4253.

Lumsden, M., J.A. Lewis and S.A. Millner (1983). Effect of composted sewage sludge on several soil borne pathogens and disease. Phytopathology, 73: 15431548.

Mertely, J.C., R.D. Martyn, M.E. Miller and B.D. Bruton (1991). Role of Monosporascuscannonballus and other fungi in root rotlvin decline disease of muskmelon. Plant Dis. 75:1133-1137.

Mansour, A.S. (2005). Pathological studies of wilt disease on strawberry in Egypt. PH.D. Thesis, Fac. Of Agric, Moshtohor, Benha Univ.,157pp.

Marschner, H. (1995). Mineral Nutrition in Plants. San Diego,CA (USA), Academic. 2nded.

Nelson, P. E., T. A. Toussoun and W. F. O.Marasas, (1982). Fusarium spp. An Illustrated Manual of Identification. The Pennesylvania Univ. Press Univ., Park, 216pp.

Noronha, F., A. Doria, P. Nogueira, M.C. Boiron and M. Cathelineau (1995). A comparative study of the fluid evolution in late-hereynian $\mathrm{W}(\mathrm{Sn}-\mathrm{Cu})$ and $\mathrm{Au}(\mathrm{As})$ quartz veins in Northern Portugal. Metallogenic implications. En: IV Congresso Nacional de Geologia. Resumosalargados. (F. sodre Borges and M. M. Marques, cords.) Men. Mus. Labar. Miner. Creol .Fac. Ciencias. Univ. Porto, 4:587-592.

Oyavrzum, P. J., M. Garlagh and A.E. Hoogland (1993). Pathogenic fungi involved in root rot of peas in the Northerlands and their physiological specialization. Netherlands Journal of Plant Pathology, 99(1): 23-33.

Pollack, F. G., and F. A. Uecker (1974). Monosporascuccannonballus an unusual ascomycete in cantaloupe roots. Mycology 66:346-349.

Ranney, C.D. and L.S. Bird (1958). Survey of the primary fungi involved in the seedling diseases of cotton. Texas Agric. ExpStn.Prog. Report. 2020: 1-3.

Rush, C.M. and J.M. Kraft (1986). Effects of inoculum density and placement on fusarium root rot peas. Phytopathology, 76(12): 1325-1329.

Rifai, W. A. (1969). A revision of the genus Trichoderma. Mycological paper No. 116. Fac. of Pure Science, Univ. of Sheffield, England, Pp 56.

Silva, F. de A. S. E. and C. A. V. de. Azevedo (2006). A New Version ofThe Assistat-Statistical Assistance Software. In: World CongressOn Computers In Agriculture, 4, Orlando-FL-USA: Anais... Orlando: American Society of Agricultural and Biological Engineers, p.393-396.

Wang, G.C., Z.F. Gu and X. Lou (1992). Studies on the pathogens of Fusarium red rot of cotton. ActaPhytopathologicalsinica, 22: 211-215.

Wassel, O.M.M., M.H.H. Ghourab and Gamalat A. Wahdan (2000). Response of cotton plant to nitrogen fertilizer and some micronutrients. Minufiya J. Agric. Res. Vol. 25(6):1413-1424. 


\section{الطرق البديله لمكافحه عفن جذور القطن}

محمد أحمد عوض(1) ، السعيد زكى خليفة(1) ، فتحية سليمان الثراكى(2) ،

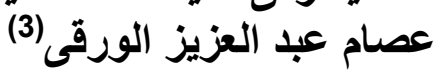

(1) قسم أمراض النبات ـ كلية الزراعة ـ جامعة المنوفية

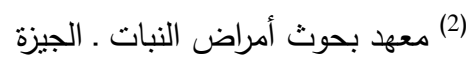

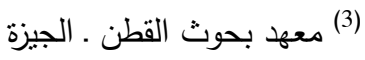

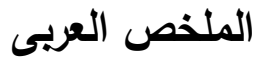

تم عزل مسببات الأمراض من عينات تربه مختلفة من نباتات القطن المصابه. و أسفرت نتائج العزل عن

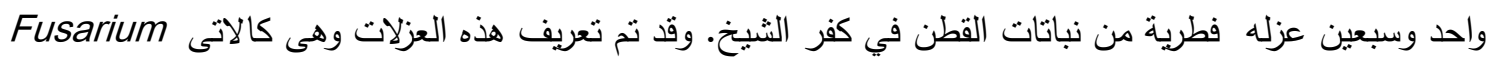
Scloratium rolfsii.Rhizoctonia solani, Macrophomina Phaseolina ،sp Rhizoctonia solani

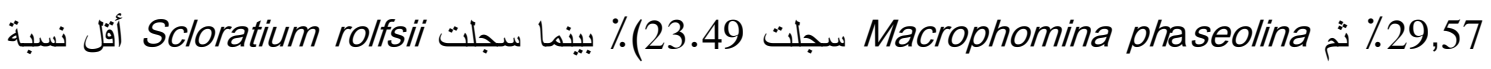
تواجد فى الفطريات المعزولة بنسبة 7,04٪ ـوعند دراسه رد فعل أصناف القطن تحت ظروف العدوى الصناعيه بالفطريات السابقه كان صنف جيزة 86 أعلى نسبة اصابه قبل وبعد الانبات. اما بالنسبه للبدائل الآمنة للمبيدات الفطريه التى تم استخدامها تم تقسيمها إلى المكافحة البيولوجية باستخدام البكتيريا (Bacillus subtilis) والفطريات (Trichoderma)، ومركبات حيوية تجارية مثل (بيوزيد، بيوارك والبلانت جارد)، ومضادات الأكسدة مثل ( حمض السلسلك، وحمض الخليك وحمض الستريك)، العناصر الصغرى ( الحديد المخلبى، الزنك المخلبى

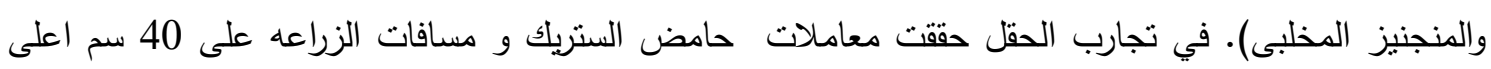

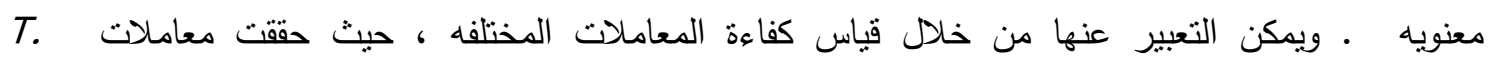
harzianum

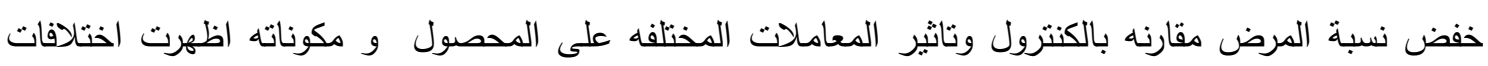
غير ملحوظة علي مكونات المحصول المختلفه. 
Awad et al., 